\title{
The Oxidation of Dibenzothiophene using Oxidovanadium(IV)-containing Nanofibres as Catalyst
}

\author{
Adeniyi S. Ogunlaja*, Eric C. Hosten and Zenixole R. Tshentu* \\ Department of Chemistry, Nelson Mandela Metropolitan University, P.O. Box 77000, Port Elizabeth, 6031, South Africa.
}

Received 3 March 2015, revised 12 June 2015, accepted 6 July 2015.

\begin{abstract}
Polyvinylbenzylchloride nanofibres were fabricated by the electrospinning technique and subsequently functionalized with a tetradentate ligand, 2,2'-(1E,1'E)-(1,2-phenylenebis(azan-1-yl-1-ylidene))bis(methan-1-yl-1-ylidene)bis(4-aminophenol). VO ${ }^{2+}$ was then incorporated into the nanofibres to produce the catalyst VO-fibres. Microanalysis, TG and FT-IR were used for the characterization of VO-fibre, and EPR also confirmed the presence of oxidovanadium(IV) within the nanofibres. Oxidation of dibenzothiophene (DBT) was investigated by varying the catalyst amount, substrate amount, oxidant and temperature, and the progress of oxidation was followed with a gas chromatograph fitted with a flame ionization detector. An increase in the amount of oxidant caused an increase in the amount of dibenzothiophene sulfone $\left(\mathrm{DBTO}_{2}\right)$, while a decrease in the quantity of dibenzothiophene resulted in an increase in the overall yield of dibenzothiophene sulfone under a constant temperature and oxidant $\left(\mathrm{H}_{2} \mathrm{O}_{2}\right)$ concentration. Dibenzothiophene sulfone was confirmed as the oxidation product through ${ }^{1} \mathrm{H}-\mathrm{NMR}$ spectroscopy and single crystal $\mathrm{X}$-ray diffraction.
\end{abstract}

KEYWORDS

Vanadium(IV) catalyst, nanofibres, dibenzothiophene, oxidation, hydrogen peroxide $\left(\mathrm{H}_{2} \mathrm{O}_{2}\right)$.

\section{Introduction}

Fuels contain sulfur compounds in which dibenzothiophene makes up about $70 \%$ of the sulfur content. ${ }^{1,2}$ On combustion of the fuel, sulfur oxides and other secondary airborne particulates are released to the atmosphere causing environmental and health concerns. ${ }^{3}$ These concerns have driven the need to reduce sulfur emissions to the atmosphere through the regulation of sulfur in transportation fuels. ${ }^{4}$

Currently, hydrodesulfurization (HDS) technology is being employed in the petroleum refining industries for the elimination of sulfur compounds through hydrogen reduction to $\mathrm{H}_{2} \mathrm{~S}$ followed by conversion to elemental sulfur. However, the process suffers a drawback in that it does not eliminate sulfur completely due to difficulties in reducing some refractory compounds such as benzothiophene, and dibenzothiophene and its alkylated derivatives. In search for a complementary approach to the HDS, biodesulfurization (BDS) and oxidative desulfurization (ODS) technologies were introduced..$^{5-17}$ Bio-desulfurization involves the use of microorganisms (e.g. bacteria) to desulfurize fuels under biological processes ${ }^{5-10}$ while the ODS process involves the oxidation of the sulfur atoms followed by the extraction of the oxidation products. ${ }^{11-17}$

Several oxidants such as nitric acid and/or nitrogen oxides, ${ }^{11}$ organic hydroperoxides, ${ }^{12,13}$ peroxyacids, ${ }^{14,15}$ and hydrogen peroxide, ${ }^{16,17}$ have been employed for the catalyzed oxidation of organosulfur compounds in fuels. Studies have shown that hydrogen peroxide appears to be a promising oxidizing agent in the catalyzed oxidation of sulfur compounds in fuels due to the fact that it offers a high amount of active oxygen and produces only water as a by-product. ${ }^{18-25}$

The activity and selectivity of metal complexes immobilized on polymer microspheres have been reported in our previous studies to be as efficient as unsupported metal complexes. ${ }^{26-29}$ In an

* To whom correspondence should be addressed.

E-mail addresses: slaja1@yahoo.com (ASO) / zenixole.tshentu@nmmu.ac.za (ZRT) attempt to improve the surface area of the polymeric support, electropsun polymer fibres have also been reportedly employed as an alternative. . $^{30-33}$

This paper describes the development of oxidovanadium(IV) catalyst immobilized on 2,2'-(1E,1'E)-(1,2-phenylenebis(azan-1yl-1-ylidene))bis(methan-1-yl-1-ylidene)bis(4-aminophenol)PVB electrospun nanofibres for the oxidation of dibenzothiophene. The oxidation reaction was monitored by varying the amount of dibenzothiophene (substrate), catalyst, $\mathrm{H}_{2} \mathrm{O}_{2}$ and temperature.

\section{Experimental}

\subsection{Materials}

Dibenzothiophene (99\%, Merck Chemicals, USA), 4-vinylbenzylchloride (90\%, Sigma-Aldrich), 2,2-azobis(isobutyronitrile) (AIBN) (98\% Sigma-Aldrich, South Africa), hydrated vanadyl sulfate $\left[\mathrm{V}^{\mathrm{IV}} \mathrm{OSO}_{4} \cdot 3 \mathrm{H}_{2} \mathrm{O}\right]$ (Sigma-Aldrich, Germany), tetrahydrofuran (THF) (99.5\%, Merck Chemical), $\mathrm{N}, \mathrm{N}$-dimethylformamide (DMF) (99\%, Merck Chemicals) and methanol (99\%, Merck Chemicals) were used as received. All other chemicals and solvents were of reagent grade.

\subsection{Instrumentation}

FT-IR spectra $\left(4000-400 \mathrm{~cm}^{-1}\right)$ were recorded on a Bruker Tensor 27 platinum ATR-FTIR spectrometer. Microanalysis was carried out using ElementarAnalysenSystemeVario ${ }^{\circledR}$ MICRO VI $6.2 \mathrm{GmbH}$. The vanadium content was determined using a Thermo Electron (iCAP 6000 Series) inductively coupled plasma - optical emission spectrometer (ICP-OES), and wavelengths with minimum interferences were chosen $(290.88 \mathrm{~nm}$, $292.40 \mathrm{~nm}, 309.31 \mathrm{~nm}$, and $311.07 \mathrm{~nm}$ ). Polymer nanofibres were imaged using a TESCAN Vega TS 5136LM scanning electron microscope (SEM). Before images were taken, the fibres were 
coated with a thin film of gold to prevent surface charging and to protect the surface material from thermal damage by the electron beam. The BET surface area and porosity analysis for the nanofibres were performed using a Micromeritics ASAP 2020. Prior to analysis the nanofibres were degassed for 10 days at $60^{\circ} \mathrm{C}$. EPR spectra were recorded on a Bruker ESP 300E X-band spectrometer. The GC conditions were as follows: Zebron Phenomenex ZB-5MSi, capillary column $(30 \mathrm{~m} \times 0.25 \mathrm{~mm} \times$ $0.25 \mu \mathrm{m})$, and helium was used as carrier gas at a flow rate of $1.63 \mathrm{~mL} \mathrm{~min}{ }^{-1}$ with an average velocity of $30.16 \mathrm{~cm} \mathrm{sec}^{-1}$ and a pressure of $63.73 \mathrm{KPa}$. The analysis run was started with an oven temperature of $80{ }^{\circ} \mathrm{C}$ ramping to $100{ }^{\circ} \mathrm{C}$ for $2 \mathrm{~min}$, and then increased to $280^{\circ} \mathrm{C}$ at a rate of $20^{\circ} \mathrm{C} \mathrm{min}$.

\subsection{Synthesis of Poly(vinylbenzylchloride) (PVBC)}

The polymerization procedure was described by Fayemi and co-workers. ${ }^{34}$ A solution of 4-vinylbenzylchloride (4-VBC) $(10 \mathrm{~mL})$ in $2 \mathrm{~mL}$ of toluene was polymerized at $70{ }^{\circ} \mathrm{C}$ for $12 \mathrm{~h}$ in the presence of 2,2-azobis(isobutyronitrile) (0.05 g) under an argon atmosphere. The resulting brown solid was dissolved in $20 \mathrm{~mL}$ of THF, and the resultant solution was transferred into a beaker containing methanol, giving rise to a white polymer precipitate of PVBC. The purification of PVBC was achieved by re-dissolving PVBC in tetrahydrofuran and re-precipitating the resultant solution into methanol. The precipitate was dried under vacuum.

\subsection{Fabrication and Functionalization of PVBC Nanofibres}

The polymer solution for electrospinning was prepared by dissolving predetermined concentrations $(50 \mathrm{wt} \%$ ) of the poly- mer in DMF:THF (1:1) and gently stirred overnight at room temperature to obtain a homogeneous solution. DMF/THF was employed as the solvent of choice due to the dielectric constant they present which enhances the electro spinning of PVBC polymer. The PVBC solution was poured into a $25 \mathrm{~mL}$ syringe attached to a needle. The syringe needle was connected to the positive electrode of high voltage power supply. The substrate collector is an aluminum foil placed on a metallic support and connected to ground. A syringe pump (74900 series, ColeParmer Instrument Company, Vernon Hills, IL) was used to supply a constant flow of polymer solution from the syringe during electro-spinning process. A voltage of $18-19 \mathrm{kV}$ was applied and the polymer solution flow rate used was between 0.05 and $0.1 \mathrm{~mL} \mathrm{~h}^{-1}$. Distance between the needle tip and the aluminum collector plate was $18 \mathrm{~cm}$. Temperature in the fume hood during the electro-spinning process was $18 \pm 3{ }^{\circ} \mathrm{C}$ for all experiments. Nanofibres, which were collected on the aluminum foil membranes, were kept overnight in the fume-hood to allow the evaporation of solvent.

\subsection{Functionalization of PVBC Nanofibres}

To $1 \mathrm{~g}(0.012 \mathrm{~mol})$ of 2,2'-(1E,1'E)-(1,2-phenylenebis(azan-1yl-1-ylidene))bis(methan-1-yl-1-ylidene)bis(4-aminophenol), ${ }^{26}$ dissolved in $10 \mathrm{~mL}$ methanol, $1 \mathrm{~g}$ of PVBC nanofibres was added, and the resulting mixture was then shaken on a mechanical shaker for $48 \mathrm{~h}$ (Scheme 1). The functionalized nanofibres were then removed, washed with excess methanol, and then dried in air. $1 \mathrm{~g}$ of functionalized nanofibres was soaked in a known solution $(0.1 \mathrm{M})$ of $\mathrm{VOSO}_{4}$ for $24 \mathrm{~h}$ to produce the resultant nanofibres (VO-fibres). Anal. Found (\%) $\mathrm{C}=76.03 ; \mathrm{H}=7.32 ; \mathrm{N}=2.83 ; \mathrm{V}=0.7$.
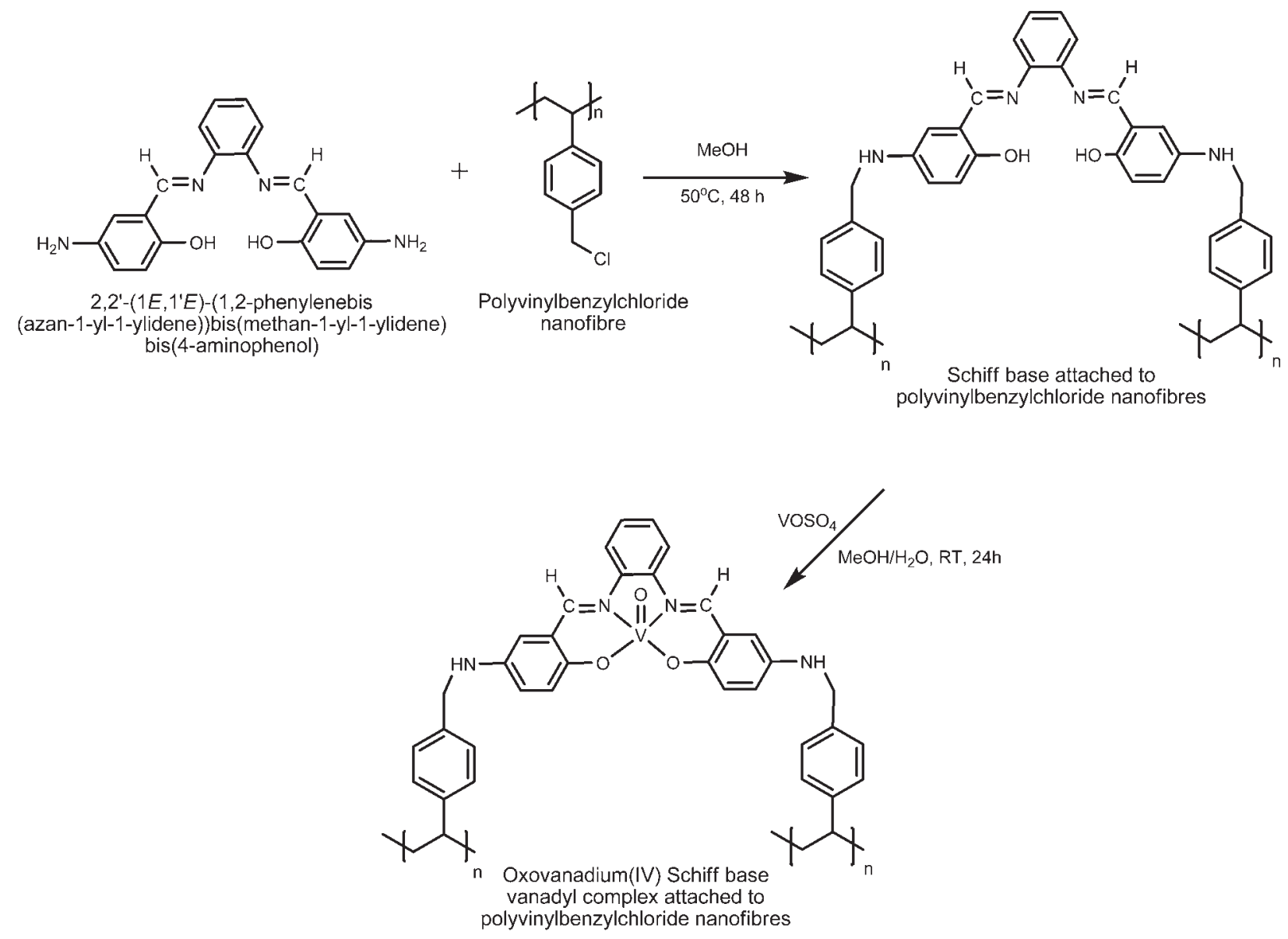

Scheme 1

Synthesis of oxidovanadium(IV) functionalized nanofibres (VO-fibre) 


\subsection{Metal Content Determination}

The vanadium content in the VO-fibres (before and after use) was determined by weighing out $0.025 \mathrm{~g}$ of material into different vials, $10 \mathrm{~mL}$ of TraceSelect $\mathrm{HNO}_{3}(69 \%)$ was added to each vial, the mixtures were heated up to a temperature of $40{ }^{\circ} \mathrm{C}$ for $12 \mathrm{~h}$ to leach out the vanadium. The acid-leached solutions were then diluted with deionized, distilled water to $100 \mathrm{~mL}$ and analyzed by using ICP-OES. ${ }^{28}$

\subsection{Oxidation of Dibenzothiophene}

The oxidation of dibenzothiophene was carried out using catalytic nanofibres in a $25 \mathrm{~mL}$ flask. In a typical reaction, an aqueous solution of $30 \% \mathrm{H}_{2} \mathrm{O}_{2}$, catalyst and dibenzothiophene in variable amount were mixed in $10 \mathrm{~mL}$ of methanol with continuous stirring at $250 \mathrm{rpm}$ in an oil bath under various temperatures. The oxidation reaction was considered to begin on addition of the required amount of the $30 \% \mathrm{H}_{2} \mathrm{O}_{2}$. Progress of the reaction was monitored by using a gas chromatograph coupled to a flame ionization detector (GC-FID), by withdrawing small aliquots after specific time intervals.

\section{Results and Discussion}

\subsection{Synthesis}

The 2,2'-(1E,1'E)-(1,2-phenylenebis(azan-1-yl-1-ylidene))bis (methan-1-yl-1-ylidene)bis(4-aminophenol) ${ }^{26}$ functionalized nanofibres (Scheme 1) presented a low nitrogen as well as vanadium content. The low nitrogen content was also observed by Fayemi et al. ${ }^{34}$ upon functionalizing PVBC with triethylenetetramine (TETA) and tris-(2-aminoethyl) amine (TAEA). The low nitrogen and vanadium loading could be attributed to functionalization reaction being carried out at room temperature to avoid harsh condition on the fibres.

\subsection{Surface Area of PVBC and VO-fibre}

Surface area measurements using carbon dioxide as adsorption gas at $273 \mathrm{~K}$ was carried out by using a Micrometrics ASAP 2020 surface area and porosity analyzer. The surface area of PVBC nanofibres was found to be $342 \mathrm{~m}^{2} \mathrm{~g}^{-1} \cdot{ }^{34}$ Upon functionalization with 2,2'-(1E,1'E)-(1,2-phenylenebis(azan-1-yl-1ylidene))bis(methan-1-yl-1-ylidene)bis(4-aminophenol) and
$\mathrm{VOSO}_{4}$ the polymer fibres surface area dropped to $122 \mathrm{~m}^{2} \mathrm{~g}^{-1}$. The reduction in surface area was due to the functionalization of PVBC on the surface.

\subsection{FT-IR Spectral Studies}

The disappearance of $\mathrm{C}-\mathrm{Cl}$ (stretching) and $\mathrm{CH}_{2}-\mathrm{Cl}$ (bending) peaks at $678 \mathrm{~cm}^{-1}$ and $1260 \mathrm{~cm}^{-1}$ respectively for polyvinylbenzylchloride (PVBC) was observed upon functionalizing with 2,2'-(1E,1'E)-(1,2-phenylenebis(azan-1-yl-1-ylidene))bis(methan -1-yl-1-ylidene)bis(4-aminophenol) and $\mathrm{VOSO}_{4}$ (Fig. 1). The broad band appearing in the region $3240-3500 \mathrm{~cm}^{-1}$ and sharp bands at $1625 \mathrm{~cm}^{-1}$ were attributed to $\mathrm{H}_{2} \mathrm{O}$ and $v(\mathrm{C}=\mathrm{N})$ (azomethine stretch) respectively, while the $v(\mathrm{~V}=\mathrm{O})$ for VO-fibres appeared at $985 \mathrm{~cm}^{-1} .26,35$

\subsection{Scanning Electron Micrograph (SEM) Images of Nanofibres}

SEM images of electrospun polyvinylbenzylchloride nanofibres as well as VO-fibres are presented in Fig. 2. The diameter of the fibres was in the range $0.15-0.28 \mu \mathrm{m}(150-280 \mathrm{~nm})$. The images show no significant change in nanofibres morphology upon functionalization of polyvinylbenzylchloride with 2,2'$\left(1 E, 1^{\prime} E\right)-(1,2-p h e n y l e n e b i s(a z a n-1-$ yl-1-ylidene)) bis(methan-1yl-1-ylidene)bis(4-aminophenol) and $\mathrm{VOSO}_{4}$. The functionalized nanofibres were generally observed to be in the diameter range of between 0.35 and $0.58 \mu \mathrm{m}(350-580 \mathrm{~nm})$.

\subsection{Thermo-gravimetric Analysis of VO-fibre}

The thermogram of VO-fibre show that the evaporation of residual solvents $(9 \%)$ occurred up to $100{ }^{\circ} \mathrm{C}$. The VO-fibre stability was mostly maintained between $100{ }^{\circ} \mathrm{C}$ and $200{ }^{\circ} \mathrm{C}$ with a loss of $2 \%$ (attributed to $\mathrm{H}_{2} \mathrm{O}$ from the vanadium salt) followed by rapid decomposition of $\mathrm{VO}$-fibre polymer backbone as well as the ligand, $2,2^{\prime}-\left(1 E, 1^{\prime} E\right)-(1,2$-phenylenebis(azan-1-yl-1ylidene))bis(methan-1-yl-1-ylidene)bis(4-aminophenol), with a weight loss of $74 \%$ in a temperature range of $205-376^{\circ} \mathrm{C}$ to give a vanadium oxide and carbon residue (Fig. 3).

\subsection{Oxidation of Dibenzothiophene}

3.6.1. Effect of Catalyst Variation

The effect of catalyst variation was studied on the oxidation of

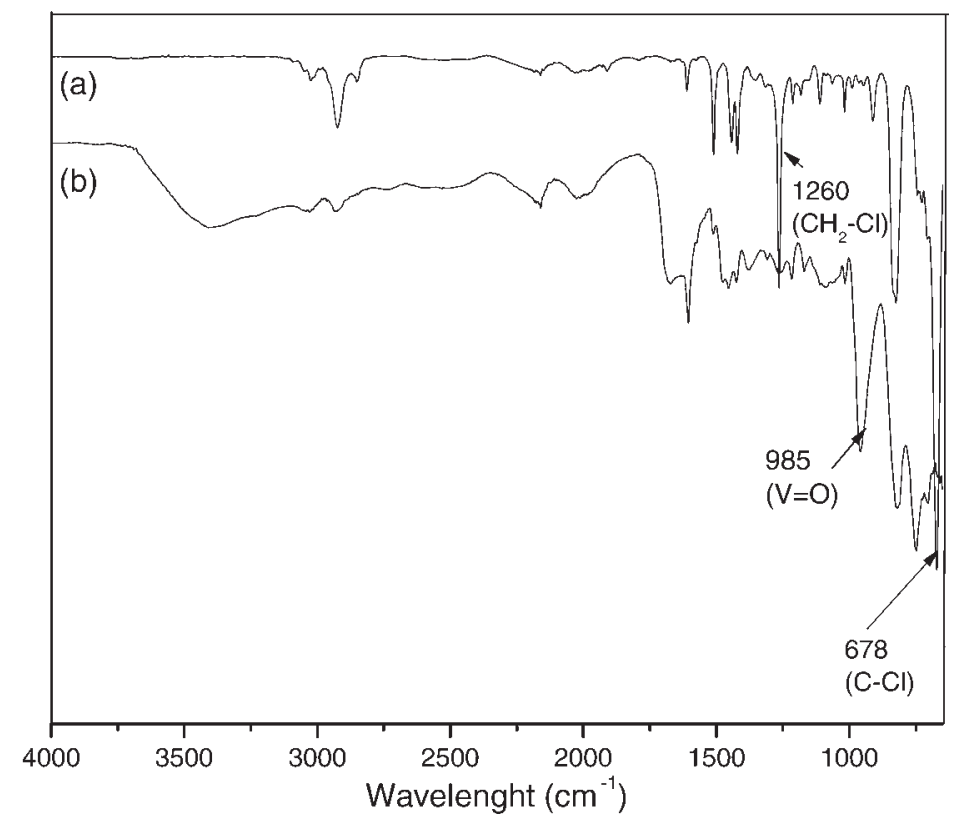

Figure 1 FT-IR adsorption spectra of (a) polyvinylbenzylchloride nanofibre and (b) VO-fibres. 


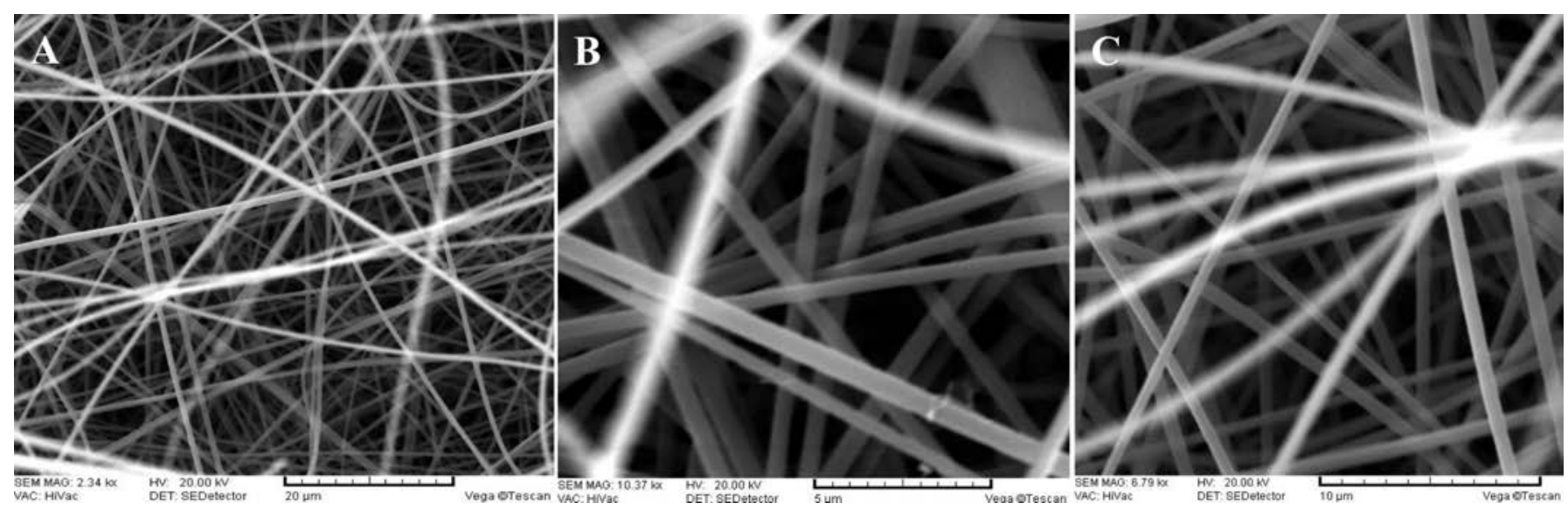

Figure 2 SEM images of (A) polyvinylbenylchloride nanofibres, (B and C) VO-fibres

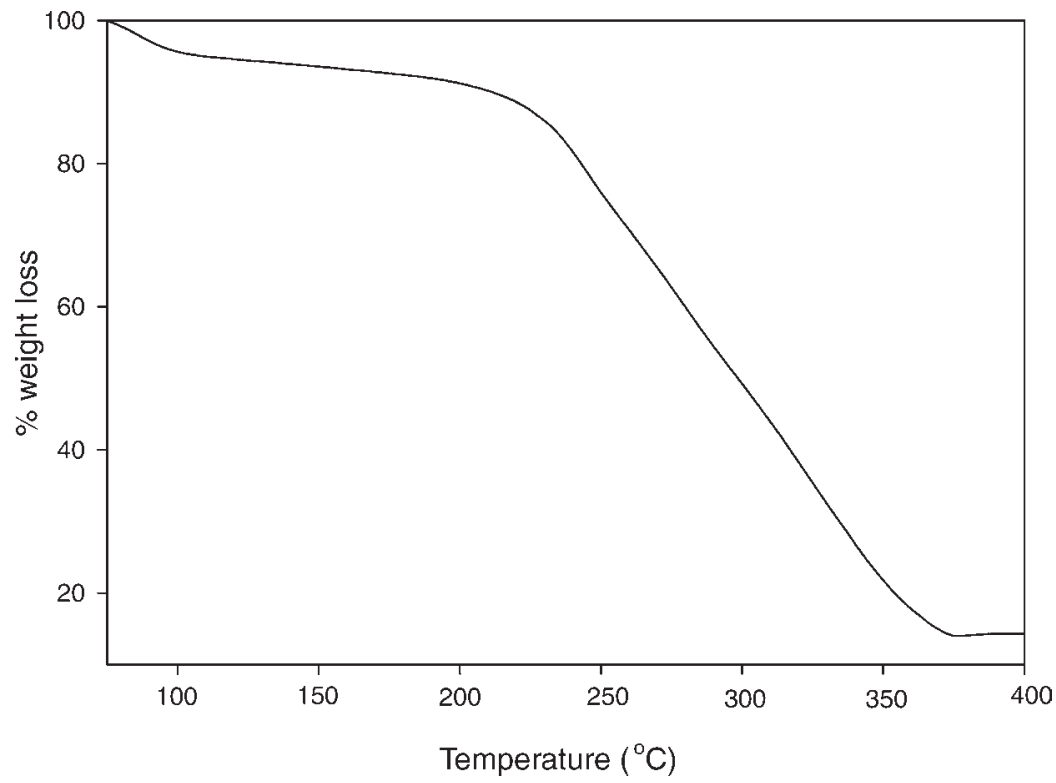

Figure 3 TG analysis profile of VO-fibre.

dibenzothiophene and it was observed that the overall oxidation yield increased with an increase in the catalyst amount (Table 1). The catalytic activity of polymer supported vanadyl complexes was studied by varying the mass of catalyst from $20 \mathrm{mg}$ $(0.0223 \mathrm{mmol})$ to $100 \mathrm{mg}(0.1115 \mathrm{mmol})$ at constant mass of dibenzothiophene $0.15 \mathrm{~g}(0.69 \mathrm{mmol})$ and hydrogen peroxide
$(0.008 \mathrm{~mol})$ in $10 \mathrm{~mL}$ of methanol at $50{ }^{\circ} \mathrm{C}$. At a catalyst mass of $100 \mathrm{mg}$ the oxidation reaction yield increased to $82 \%(80 \%$ sulfone and $2 \%$ sulfoxide) (Fig. 4). The reaction was observed to produce an overall conversion of less than $17 \%$ in the absence of the catalyst. ${ }^{26}$ The turnover frequency (TOF) for dibenzothiophene decreased from 441 to $113 \mathrm{~h}^{-1}$ (Table 1). A plot of mass

Table 1 Percentage conversions and turnover frequencies (TOF) from varying the catalyst, $\mathrm{H}_{2} \mathrm{O}_{2}$ and dibenzothiophene.

\begin{tabular}{|c|c|c|c|c|c|c|}
\hline Substrate & $\begin{array}{c}\text { Catalyst } \\
/ \times 10^{-6} \text { moles }\end{array}$ & $\begin{array}{c}\text { Catalyst mass } \\
\qquad / \mathrm{mg}\end{array}$ & $\begin{array}{c}\mathrm{H}_{2} \mathrm{O}_{2} \text { amount } \\
\text { moles }\end{array}$ & $\begin{array}{l}\text { Substrate } \\
/ \text { moles } \times 10^{-4}\end{array}$ & $\%$ conversion & $\begin{array}{l}\text { TOF } \\
/ \mathrm{h}^{-1} \text { a }\end{array}$ \\
\hline Dibenzothiophene & 0.67 & 20 & 0.008 & 6.94 & 64.0 & 442 \\
\hline Dibenzothiophene & 1.34 & 40 & 0.008 & 6.94 & 70.6 & 244 \\
\hline Dibenzothiophene & 2.01 & 60 & 0.008 & 6.94 & 74.8 & 172 \\
\hline Dibenzothiophene & 3.34 & 100 & 0.008 & 6.94 & 81.2 & 113 \\
\hline Dibenzothiophene & 1.67 & 50 & 0.001 & 6.94 & 63.2 & 175 \\
\hline Dibenzothiophene & 1.67 & 50 & 0.008 & 6.94 & 95.4 & 264 \\
\hline Dibenzothiophene & 1.67 & 50 & 0.014 & 6.94 & 98.6 & 273 \\
\hline Dibenzothiophene & 1.67 & 50 & 0.019 & 6.94 & 99.5 & 276 \\
\hline Dibenzothiophene & 1.67 & 50 & 0.008 & 4.63 & 90.7 & 168 \\
\hline Dibenzothiophene & 1.67 & 50 & 0.008 & 7.40 & 81.0 & 239 \\
\hline Dibenzothiophene & 1.67 & 50 & 0.008 & 9.26 & 80.0 & 296 \\
\hline Dibenzothiophene & 1.67 & 50 & 0.008 & 13.89 & 70.2 & 389 \\
\hline
\end{tabular}

${ }^{\mathrm{a}} \mathrm{TOF}, \mathrm{h}^{-1}$ : (turnover frequency) moles of substrate converted per mole of metal ion (in the solid state catalyst) per hour. All experiments were carried-out at $50{ }^{\circ} \mathrm{C}$. 
of catalyst (vanadium + support) against \% conversion (Fig. 4) suggests a linear relationship but a plot of the actual moles of vanadium against \% conversion showed a slight decrease in $\%$ conversion with an increase in moles of vanadium (Fig. 5), and this may be attributed to diffusion constraints when larger quantities of fibre are used.

\subsubsection{Effect of Oxidant Concentration}

Varying the $\mathrm{H}_{2} \mathrm{O}_{2}$ concentration on oxidation of dibenzothiophene at constant amount of dibenzothiophene $(0.15 \mathrm{~g}$, $0.69 \mathrm{mmol}$ ) and catalyst $(50 \mathrm{mg})$ at $50{ }^{\circ} \mathrm{C}$ resulted in the production of a higher amount of dibenzothiophene oxides under different conditions (Table 1).

An increase in the concentration of oxidant was observed to have a positive effect on the overall yield of dibenzothiophene sulfone. At oxidant amount of $0.001 \mathrm{~mol}$, an oxidation yield of $69 \%$ was observed, upon increasing the oxidant concentration to a maximum of $0.019 \mathrm{~mol}$ the overall reaction yield also increased to $99 \%$ (Fig. 6). A large amount of oxidant in the reaction mixture, however, resulted in the leaching of vanadium from the catalyst support. A much higher selectivity for dibenzothiophene sulfone in the oxidation was influenced by a

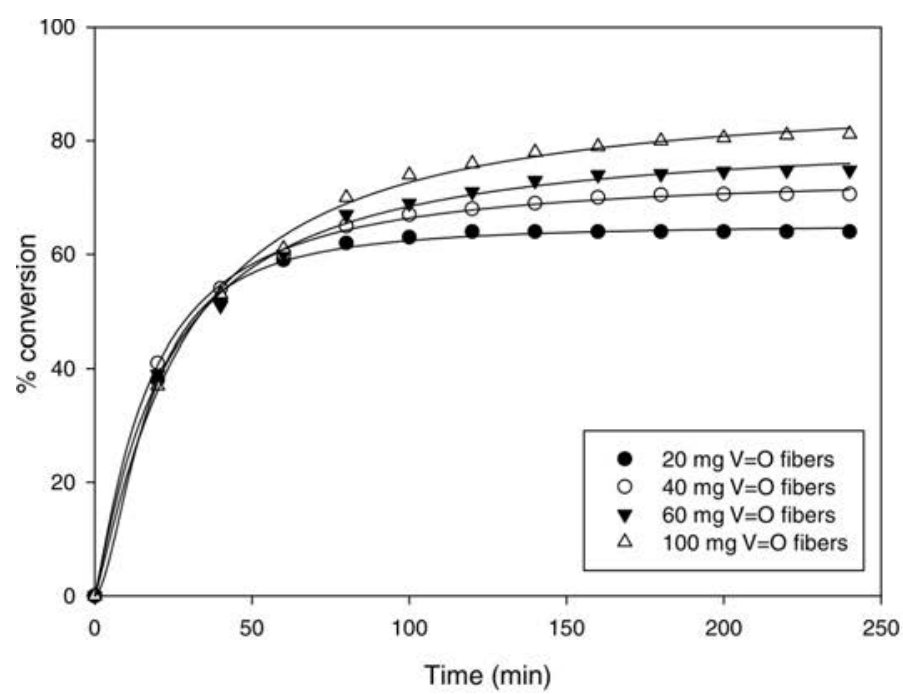

higher concentration of hydrogen peroxide while more dibenzothiophene sulfoxide was produced at lower amount of oxidant (Fig. 6). The turnover frequency (TOF) of dibenzothiophene oxidation varied between 175 and $276 \mathrm{~h}^{-1}$ (Table 1).

\subsubsection{Effect of Dibenzothiophene Concentration}

The oxidation of dibenzothiophene was studied by varying its mass (mole) from $0.1 \mathrm{~g}(0.463 \mathrm{mmol})$ to $0.3 \mathrm{~g}(1.389 \mathrm{mmol})$ while a constant amount of $\mathrm{H}_{2} \mathrm{O}_{2}(0.008 \mathrm{~mol})$ and catalyst $(0.00167 \mathrm{mmol})$ were used in the reaction mixture at $40^{\circ} \mathrm{C}$ using $10 \mathrm{~mL}$ methanol. From the oxidation studies of dibenzothiophene, an increase in the amount of dibenzothiophene at constant amount of $\mathrm{H}_{2} \mathrm{O}_{2}$ and catalyst resulted in a decrease in dibenzothiophene sulfone yield. A maximum overall oxidation yield of $91.7 \%$ (90.6\% sulfone and $1.1 \%$ sulfoxide) was observed. The selectivity for dibenzothiophene sulfone in the oxidation system was influenced by the decrease in the concentration of dibenzothiophene and selectivity for dibenzothiophene sulfoxide was observed as the amount of dibenzothiophene was increased, and this was attributed to the low amount of oxidant available for the further oxidation of the sulfoxide when a high quantity of dibenzothiophene is used (Fig. 7). The turnover frequency (TOF) for the

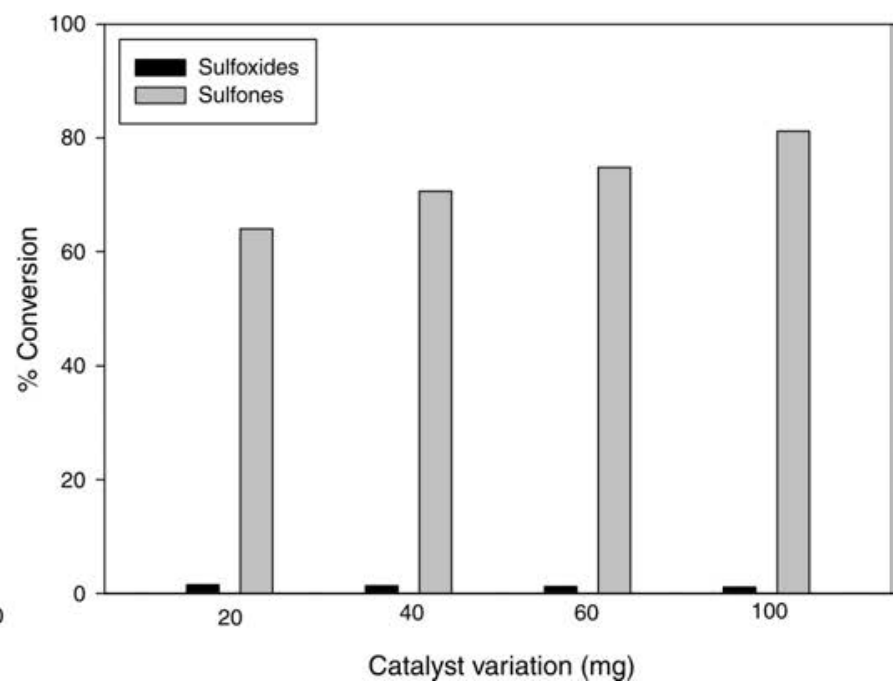

Figure 4 Effect of amount of catalyst on the oxidation of dibenzothiophene. $\left[\mathrm{H}_{2} \mathrm{O}_{2}\right]=0.008 \mathrm{~mol}$; [dibenzothiophene] $=0.15 \mathrm{~g}(0.69 \mathrm{mmol})$; temp.: $50{ }^{\circ} \mathrm{C}$.; $\mathrm{MeOH}=10 \mathrm{~mL}$.

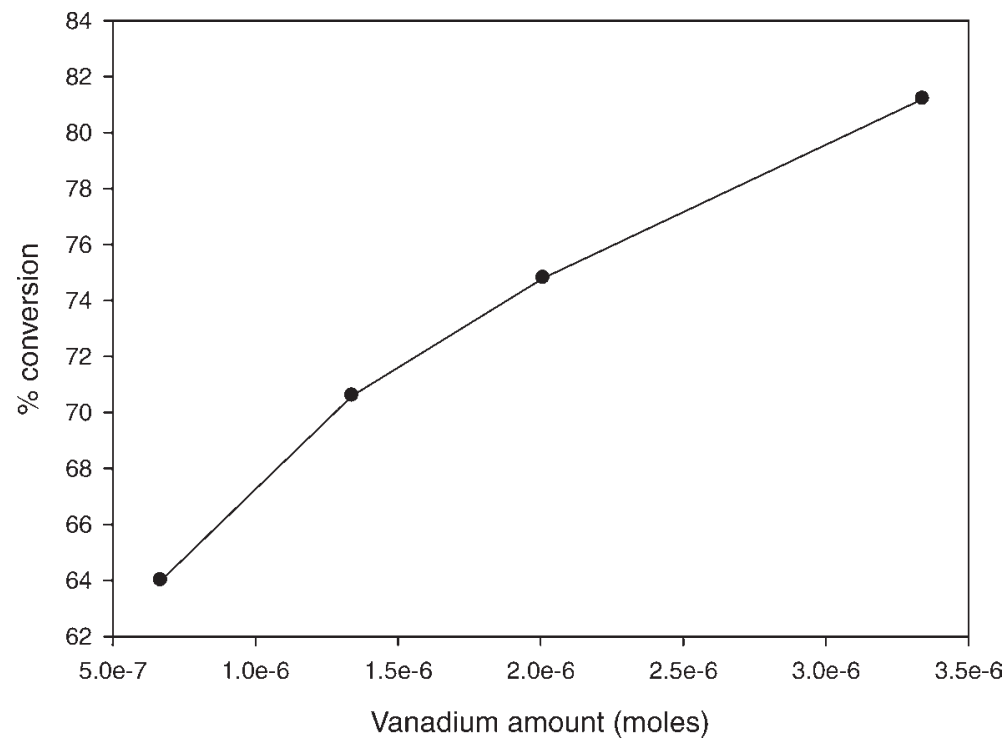

Figure 5 Plot of vanadium amount (moles) against \% conversion. 
oxidation of dibenzothiophene during dibenzothiophene variation in the presence of VO-fibre catalyst varied from 168 to $389 \mathrm{~h}^{-1}$ (Table 1$)$.

\subsubsection{Effect of Temperature Variation}

The oxidation reaction was studied at three different temperatures $40^{\circ} \mathrm{C}, 55^{\circ} \mathrm{C}$ and $70^{\circ} \mathrm{C}$. The rate of oxidation increased with an increase in temperature, suggesting that the reacting molecules collide more often at an elevated temperature. The selectivity for dibenzothiophene sulfone in the oxidation reaction was also influenced by the increase in the temperature and selectivity for dibenzothiophene sulfoxide was favoured by a decrease in temperature (Fig. 8). The turnover frequency (TOF) for oxidation of dibenzothiophene during the temperature variation in the presence of catalyst varied from 175 to $273 \mathrm{~h}^{-1}$ (Table 2).

\subsection{EPR Studies}

The presence $\mathrm{V}^{\mathrm{IV}} \mathrm{O}$-ligand species in VO-fibre was ascertained by EPR. The EPR spectra of VO-fibre before and after use are presented in Fig. 9. $\mathrm{V}^{4+}$ species exhibit a hyperfine structure derived from the interaction of free electrons $\left(3 \mathrm{~d}^{1}\right)$ with the magnetic nuclear moment of ${ }^{51} \mathrm{~V}(I=7 / 2)$, and the EPR signal should split eightfold. ${ }^{26}$ The additional splitting displayed by the catalyst,

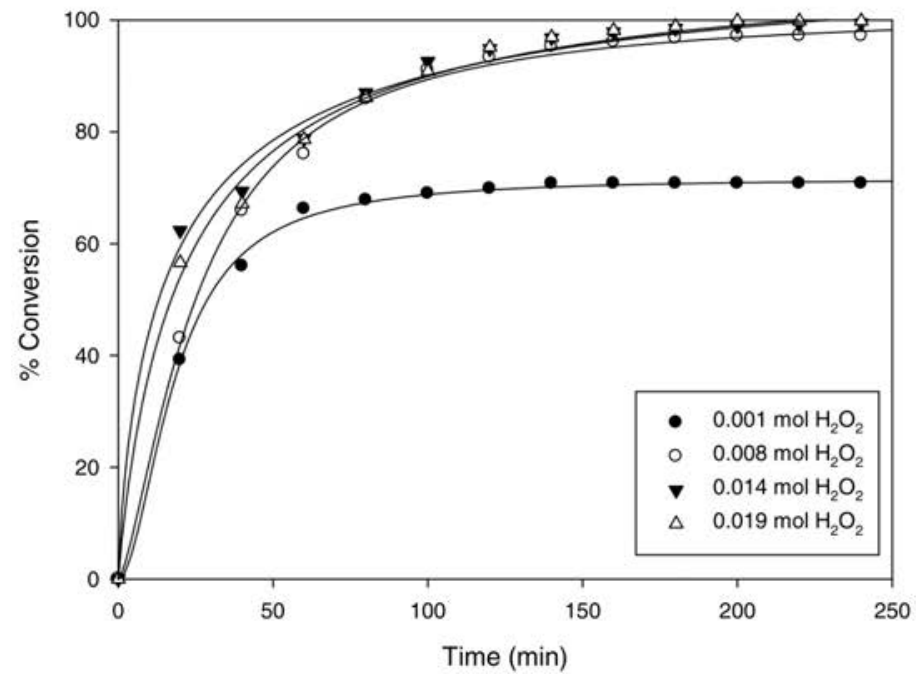

Table 2 Percentage conversion and turnover frequency (TOF) at various temperatures

\begin{tabular}{lccccc}
\hline $\begin{array}{l}\text { Temp. } \\
\left({ }^{\circ} \mathrm{C}\right)\end{array}$ & $\begin{array}{c}\% \text { conver- } \\
\text { sion }\end{array}$ & $\begin{array}{c}\text { TOF } \\
/ \mathrm{h}^{-1}\end{array}$ & $\begin{array}{c}\text { Catalyst } \\
/ \text { moles } \times 10^{-6}\end{array}$ & $\begin{array}{c}\mathrm{H}_{2} \mathrm{O}_{2} \\
/ \text { moles }\end{array}$ & $\begin{array}{c}\text { Substrate } \\
/ \text { moles } \times 10^{-4}\end{array}$ \\
\hline 40 & 78.2 & 175 & 1.67 & 0.008 & 6.94 \\
55 & 84.7 & 264 & 1.67 & 0.008 & 6.94 \\
70 & 90.3 & 273 & 1.67 & 0.008 & 6.94 \\
\hline
\end{tabular}

VO-fibre and recycled VO-fibre, was due to the anisotropic nature of the magnetic moment of vanadyl on the polymer support. ${ }^{36}$ A slightly different splitting pattern was observed on the spectrum of the recycled catalyst (Fig. 9) and was attributed to a possible change in the vanadium environment, i.e. the complex is recovered in a slightly different coordination environment. The anisotropic spectrum of VO-fibre showed $g=1.9567$ and $\mathrm{A}=161.2 \times 10^{-4} \mathrm{~cm}^{-1}$, and the recycled VO-fibre parameters gave a $\mathrm{g}=1.9653$ and $\mathrm{A}=158.4 \times 10^{-4} \mathrm{~cm}^{-1}$.

\subsection{Catalytic Mechanism of Oxidovanadium(IV)-catalyzed Oxidation of Dibenzothiophene}

$\mathrm{UV} / \mathrm{Vis}$ studies showed that intermediate species were formed

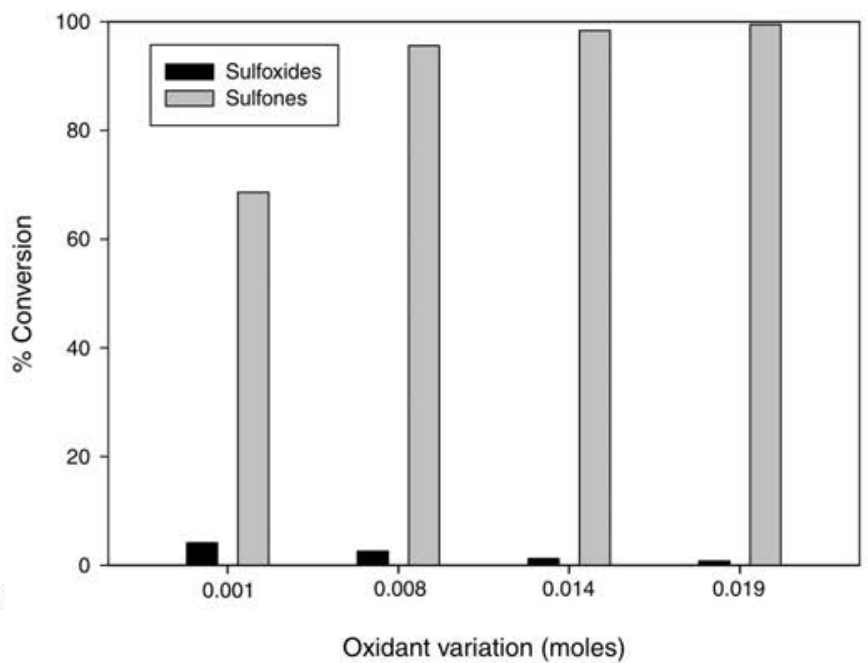

Figure 6 Percentage selectivity of the $\mathrm{H}_{2} \mathrm{O}_{2}$ variation on the oxidation of dibenzothiophene. [Catalyst] $=1.67 \times 10^{-6}$ mol; [dibenzothiophene] $=0.15 \mathrm{~g}$ $(0.69 \mathrm{mmol})$; temp.: $50^{\circ} \mathrm{C}$; $\mathrm{MeOH}=10 \mathrm{~mL}$.
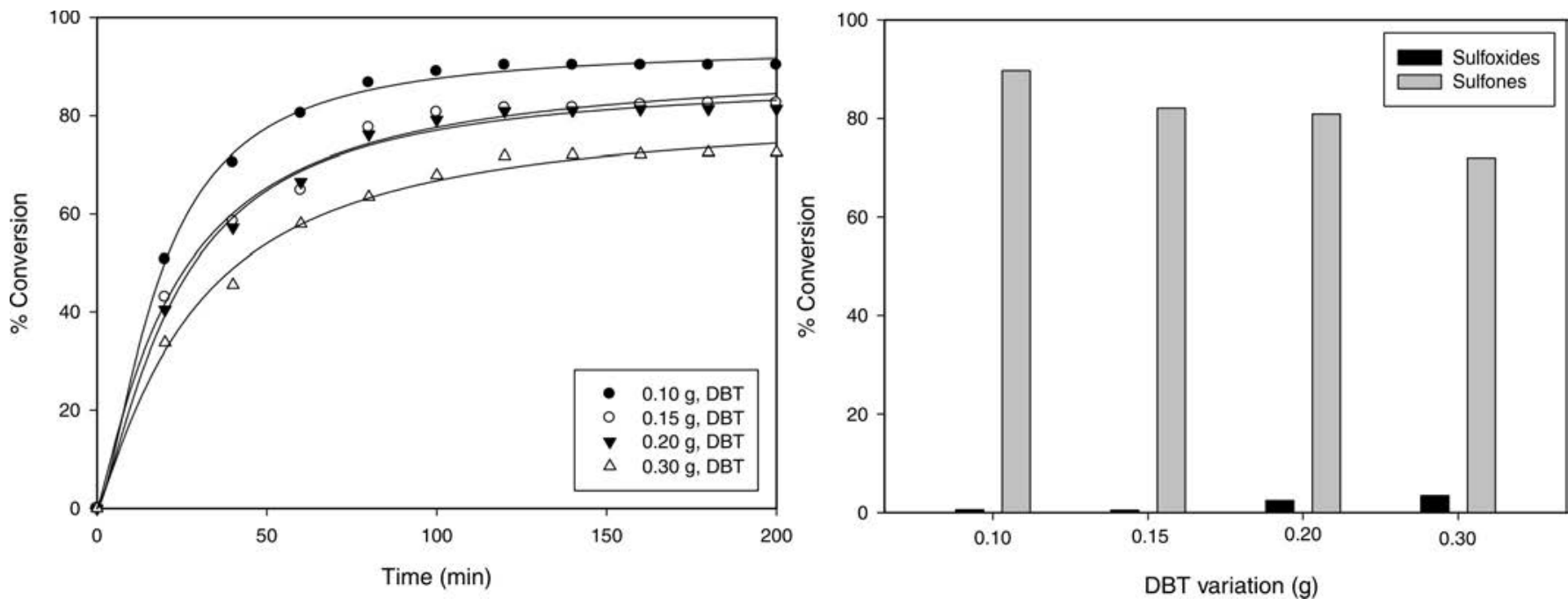

Figure 7 Effect of varying the amount of dibenzothiophene. $\left[\mathrm{H}_{2} \mathrm{O}_{2}\right]=0.008 \mathrm{~mol}$; [catalyst $]=1.67 \times 10^{-6} \mathrm{~mol}$; temp.: $50^{\circ} \mathrm{C} ; \mathrm{MeOH}=10 \mathrm{~mL}$. 

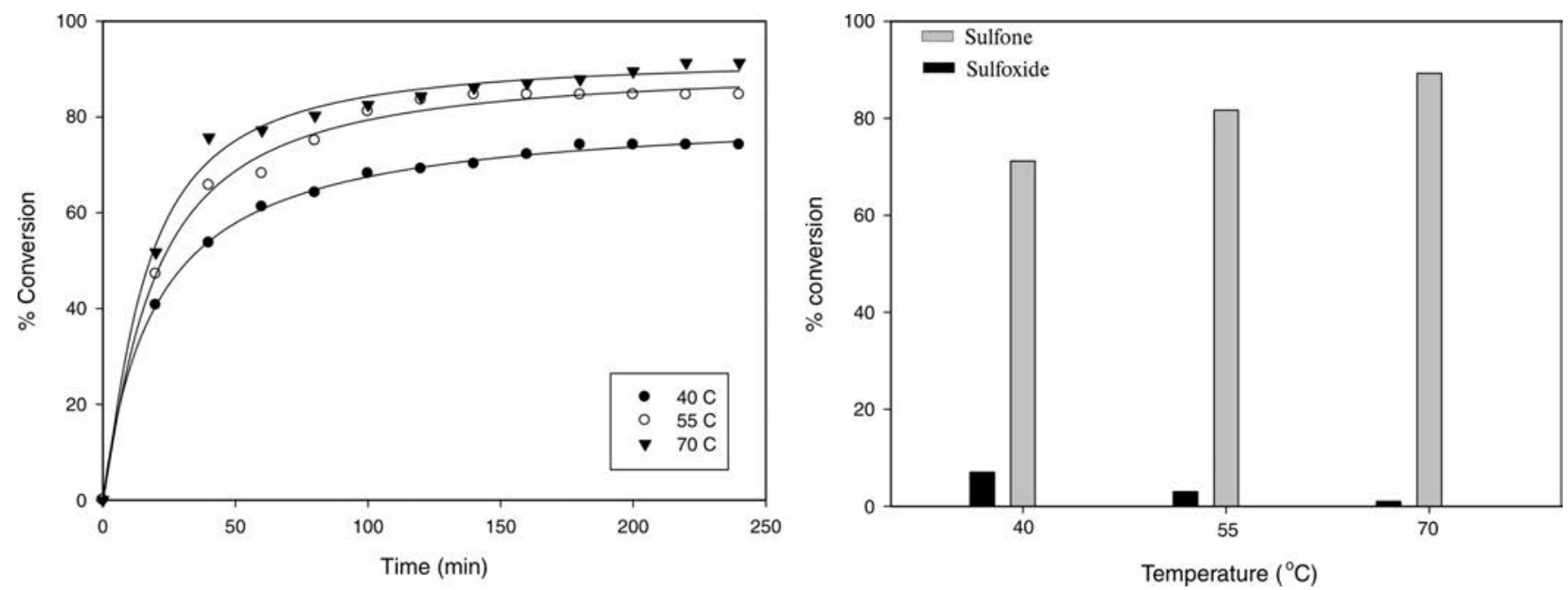

Figure 8 Effect of temperature variation on the oxidation of dibenzothiophene. $\left[\mathrm{H}_{2} \mathrm{O}_{2}\right]=0.008 \mathrm{~mol}$; $[$ catalyst $]=1.67 \times 10^{-6} \mathrm{~mol}$; $[\mathrm{dibenzothiophene}]=$ $0.15 \mathrm{~g}(0.69 \mathrm{mmol}) ; \mathrm{MeOH}=10 \mathrm{~mL}$.

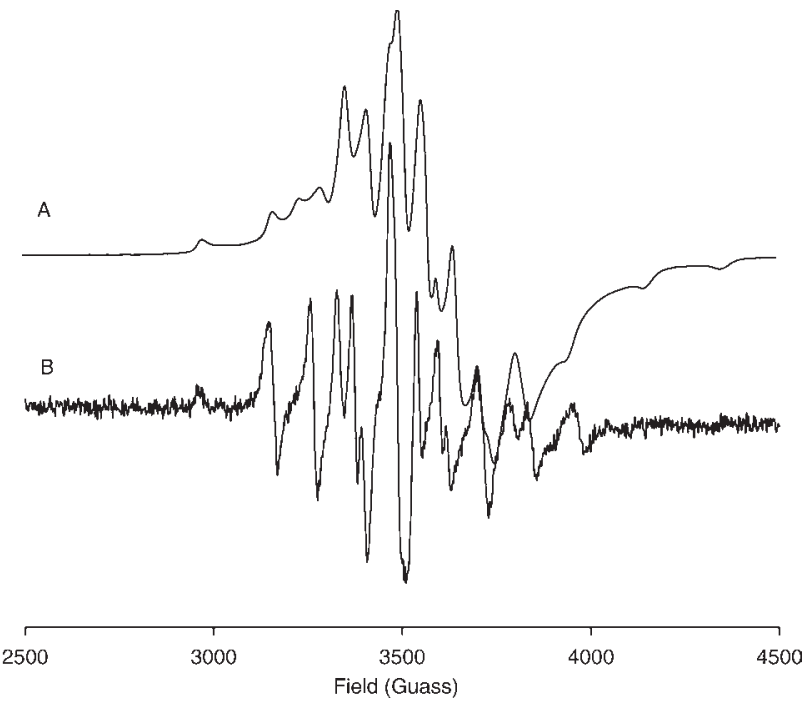

Figure 9 EPR spectra of (A) VO-fibre before use and (B) VO-fibre after use.

during the catalytic oxidation process; oxidovanadium(IV) was oxidized to dioxidovanadium(V) and oxidoperoxido species. ${ }^{29}$ The peroxo protonates to form the hydroxyl-peroxidovana$\operatorname{dium}(\mathrm{V})$ species. Electron pairing between the sulfur atom of dibenzothiophene and an oxygen atom of the hydroxylperoxidovanadium $(\mathrm{V})$ species resulted in bond formation therefore, giving rise to the oxidation product (Scheme 2). Dibenzothiophene sulfoxide is first formed; further oxidation resulted in the formation of dibenzothiophene sulfone (Scheme 3).

\subsection{Product Analysis}

\subsection{1. ${ }^{1} H-N M R$ and FT-IR}

A white crystalline solid, dibenzothiophene sulfone, was obtained as the catalyzed oxidation product of dibenzothiophene. The oxidation product was characterized by using nuclear

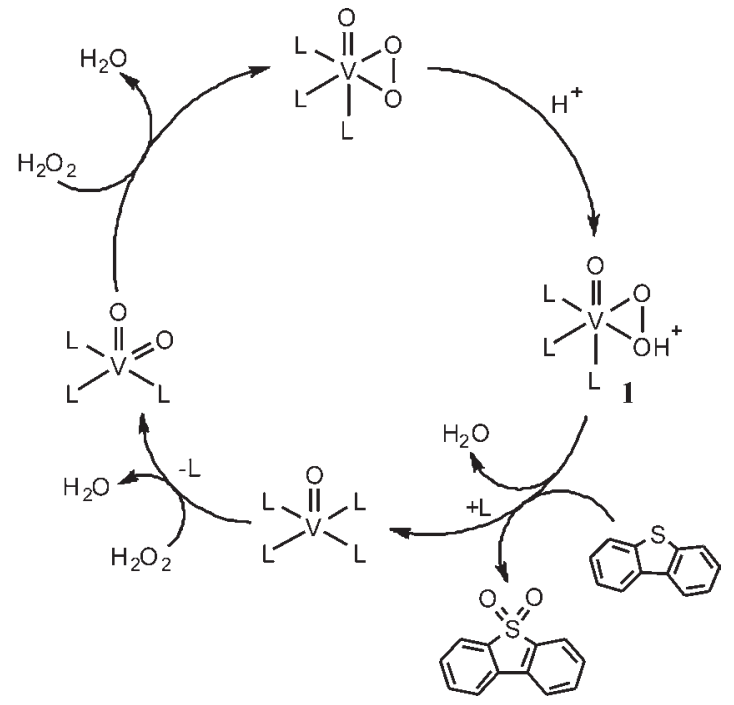

Scheme 2

Simplified catalytic mechanism for the oxidation of dibenzothiophene. $\mathrm{H}^{+}$from $\mathrm{H}_{2} \mathrm{O}$ may protonate peroxo to form the hydroxyl-peroxidovanadium $(V)$ species (1). Here L may refer to donor atom.

magnetic resonance (NMR) spectroscopy and Fourier transform infrared (FT-IR) spectroscopy. ${ }^{1} \mathrm{H}-\mathrm{NMR} \delta_{\mathrm{H}}(400 \mathrm{MHz}, \mathrm{DMSO})$ : $8.22(\mathrm{~d}, J=7.7,2 \mathrm{H}), 8.00(\mathrm{~d}, J=7.6,2 \mathrm{H}), 7.82(\mathrm{t}, J=7.6,2 \mathrm{H}), 7.67(\mathrm{t}$, $J=7.6,2 \mathrm{H})$. FT-IR $\left(\mathrm{cm}^{-1}\right): 1354 \mathrm{~cm}^{-1} v(\mathrm{~S}=\mathrm{O}), 755 \mathrm{~cm}^{-1} v(\mathrm{C}-\mathrm{S})$, $1520 \mathrm{~cm}^{-1} v(\mathrm{C}=\mathrm{C}){ }^{26,27}$

\subsubsection{Structure Determination and Refinement of Dibenzothiophene} Sulfone

Single crystals of dibenzothiophene sulfone suitable for X-ray analysis were produced on oxidation of dibenzothiophene and allowing the solvents to evaporate slowly. Intensity data were collected on a Bruker APEX II CCD diffractometer with graphite monochromated Mo K $\alpha$ radiation using the APEX 2 data collection software. ${ }^{37}$ The molecular structure is presented in Fig. 10.

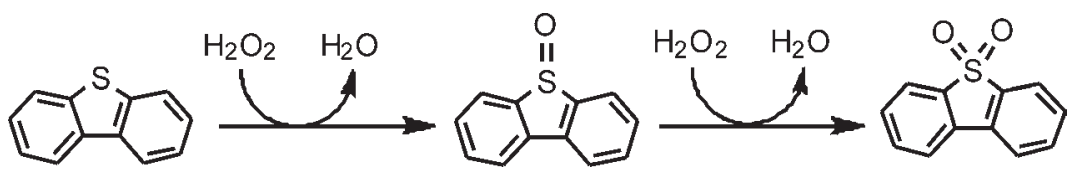

Scheme 3

Oxidation reaction scheme of dibenzothiophene using hydrogen peroxide $\left(\mathrm{H}_{2} \mathrm{O}_{2}\right)$. 


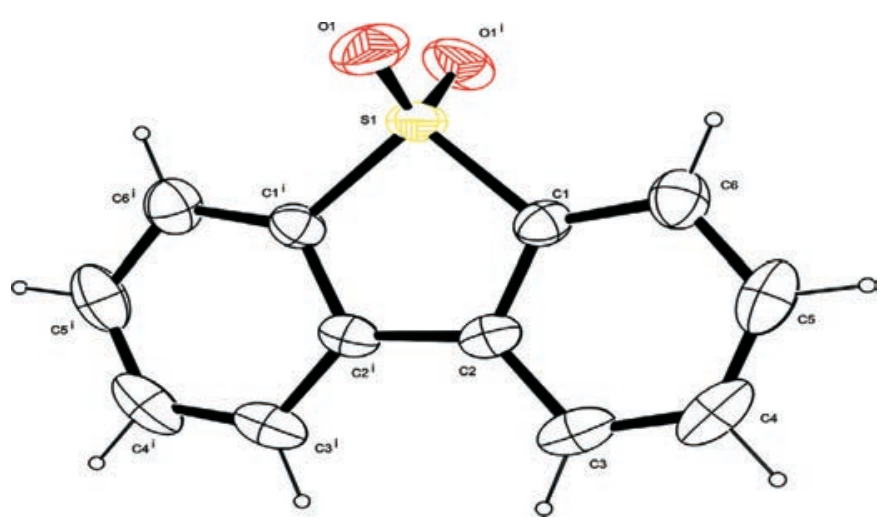

Figure 10 An ORTEP view of dibenzothiophene sulfone with ellipsoids drawn at $50 \%$ probability level.

Crystal data and details for the determination of the structure are presented in Table 3. The structure was solved by direct methods applying SHELXS-2013 and refined by least-squares procedures using SHELXL-2013. ${ }^{38}$ The crystal structure diagram was drawn with ORTEP-3 for windows. ${ }^{39}$ The bond distances between sulfur and oxygen are quite short, hence confirming the formation of double bonds between sulfur $(\mathrm{S})$ and oxygen (O) atoms. The bond distances and angles between atoms within the molecule are presented in Table 4 .

\subsection{Reusability Studies}

The reusability of the catalyst, VO-fibre, was studied to establish the activity of the catalyst using the following conditions: $\left[\mathrm{H}_{2} \mathrm{O}_{2}\right]=0.005 \mathrm{~mol}$; [catalyst] $=1.67 \times 10^{-6} \mathrm{~mol}$; [dibenzothiophene $]=0.15 \mathrm{~g}(0.69 \mathrm{mmol}) ; \mathrm{MeOH}=10 \mathrm{~mL}$ and temp.: $55^{\circ} \mathrm{C}$. The VO-fibre catalyst showed a decreased activity on the second and third cycles. The overall oxidation of dibenzothiophene for the second and third cycle was $80 \%$ and $76 \%$, respectively, compared with $85 \%$ obtained in the first cycle. The reduction in catalyst activity was attributed to the leaching of vanadium from VO-fibre, and $21 \%$ vanadium was leached into solution after the first oxidation cycle.

Table 3 Crystal data and details of the structure determination for dibenzothiophene sulfone.

\begin{tabular}{|c|c|}
\hline Formula & $\mathrm{C}_{12} \mathrm{H}_{8} \mathrm{O}_{2} \mathrm{~S}$ \\
\hline Formula weight & 216.24 \\
\hline Crystal system & Monoclinic \\
\hline Space group & C2/c (No. 15) \\
\hline$a, b, c /$ Angstrom & $10.0514(6) 13.8184(6) 7.0487(4)$ \\
\hline $\mathrm{V} / \mathrm{Ang}^{* * 3}$ & $978.73(9)$ \\
\hline $\mathrm{Z}$ & 4 \\
\hline $\mathrm{D}($ calc $) / \mathrm{g} \mathrm{mL}^{-1}$ & 1.468 \\
\hline $\mathrm{Mu}(\mathrm{MoKa}) / \mathrm{mm}$ & 0.302 \\
\hline $\mathrm{F}(000)$ & 448 \\
\hline Crystal size $/ \mathrm{mm}$ & $0.07 \times 0.19 \times 0.63$ \\
\hline Temperature /K & 200 \\
\hline Radiation /Angstrom & $\operatorname{MoK} \alpha \quad 0.71073$ \\
\hline Theta min-max /Deg & $2.5,28.4$ \\
\hline Dataset & $-13: 13 ;-18: 13 ;-9: 9$ \\
\hline Tot., uniq. data, R(int) & $4723,1226,0.033$ \\
\hline Observed data /I > 2.0 sigma(I) & 1049 \\
\hline Nref, Npar & 1226,69 \\
\hline $\mathrm{R}, \mathrm{wR} 2, \mathrm{~S}$ & $0.0346,0.0967,1.07$ \\
\hline Max. and av. shift/error & $0.00,0.00$ \\
\hline Min. and max. resd. dens. /e/Ang^3 & $-0.30,0.32$ \\
\hline
\end{tabular}

Table 4 Bond distances (Angstrom) and bond angles $\left(^{\circ}\right)$ of dibenzothiophene sulfone.

\begin{tabular}{|c|c|c|c|}
\hline Bond lengths & $/ \AA ̊$ & Bond angles & p \\
\hline$S(1)-O(1)$ & $1.4389(13)$ & $\mathrm{O}(1)-\mathrm{S}(1)-\mathrm{C}(1)$ & $110.27(7)$ \\
\hline$S(1)-C(1)$ & $1.7560(14)$ & $\mathrm{O}(1)-\mathrm{S}(1)-\mathrm{O}(1 \mathrm{a})$ & $117.35(8)$ \\
\hline $\mathrm{S}(1)-\mathrm{O}(1 \mathrm{a})$ & $1.4389(13)$ & $\mathrm{O}(1)-\mathrm{S}(1)-\mathrm{C}(1 \mathrm{a})$ & $111.49(7)$ \\
\hline$S(1)-C(1 a)$ & $1.7560(14)$ & $\mathrm{O}(1 \mathrm{a})-\mathrm{S}(1)-\mathrm{C}(1)$ & $111.49(7)$ \\
\hline$C(1)-C(2)$ & $1.394(2)$ & $C(1)-S(1)-C(1 a)$ & $93.48(7)$ \\
\hline$C(1)-C(6)$ & $1.381(2)$ & $\mathrm{O}(1 \mathrm{a})-\mathrm{S}(1)-\mathrm{C}(1 \mathrm{a})$ & $110.27(7)$ \\
\hline$C(2)-C(3)$ & $1.389(2)$ & $S(1)-C(1)-C(2)$ & $110.42(10)$ \\
\hline$C(2)-C(2 a)$ & $1.476(2)$ & $S(1)-C(1)-C(6)$ & $126.13(12)$ \\
\hline $\mathrm{C}(3)-\mathrm{C}(4)$ & $1.387(3)$ & $C(2)-C(1)-C(6)$ & $123.44(14)$ \\
\hline$C(4)-C(5)$ & $1.378(3)$ & $\mathrm{C}(1)-\mathrm{C}(2)-\mathrm{C}(3)$ & $118.14(14)$ \\
\hline$C(5)-C(6)$ & $1.386(3)$ & $C(1)-C(2)-C(2 a)$ & $112.83(12)$ \\
\hline $\mathrm{C}(3)-\mathrm{H}(3)$ & 0.9500 & $C(2 a)-C(2)-C(3)$ & $129.03(13)$ \\
\hline $\mathrm{C}(4)-\mathrm{H}(4)$ & 0.9500 & $C(2)-C(3)-C(4)$ & $119.03(15)$ \\
\hline C(5)-H(5) & 0.9500 & $C(3)-C(4)-C(5)$ & $121.60(17)$ \\
\hline $\mathrm{C}(6)-\mathrm{H}(6)$ & 0.9500 & $C(4)-C(5)-C(6)$ & $120.63(16)$ \\
\hline- & - & $C(1)-C(6)-C(5)$ & 117.17(16) \\
\hline - & - & $\mathrm{C}(2)-\mathrm{C}(3)-\mathrm{H}(3)$ & 120.00 \\
\hline - & - & $\mathrm{C}(4)-\mathrm{C}(3)-\mathrm{H}(3)$ & 121.00 \\
\hline- & - & $\mathrm{C}(3)-\mathrm{C}(4)-\mathrm{H}(4)$ & 119.00 \\
\hline - & - & $\mathrm{C}(5)-\mathrm{C}(4)-\mathrm{H}(4)$ & 119.00 \\
\hline - & - & $\mathrm{C}(4)-\mathrm{C}(5)-\mathrm{H}(5)$ & 120.00 \\
\hline - & - & $\mathrm{C}(6)-\mathrm{C}(5)-\mathrm{H}(5)$ & 120.00 \\
\hline - & - & $\mathrm{C}(1)-\mathrm{C}(6)-\mathrm{H}(6)$ & 121.00 \\
\hline - & - & $\mathrm{C}(5)-\mathrm{C}(6)-\mathrm{H}(6)$ & 121.00 \\
\hline
\end{tabular}

\section{Conclusions}

The polymer nanofibres containing vanadyl ion were fabricated. EPR studies confirmed the presence of V(IV) within the polymer nanofibres and also indicated that $\mathrm{V}(\mathrm{V})$ was recycled back to V(IV) after the oxidation cycle. The catalyst, VO-fibres, showed activity towards dibenzothiophene oxidation, and the reduction in the catalyst activity after the first cycle was attributed to the leaching of vanadium from VO-fibre. VO-fibre will probably be useful under continuous flow oxidation in order to limit the catalyst leaching rather than the batch oxidation reaction procedure carried out in this account.

\section{Supplementary Information}

CCDC 1051696 contains the supplementary crystallographic data for this paper. This data can be obtained free of charge from The Cambridge Crystallographic Data Centre via www.ccdc.cam.ac.uk/data_request/cif

\section{References}

1 B.C. Gates and H. Topsoe, Reactivities in deep catalytic hydrodesulfurization: challenges, opportunities, and the importance of 4-methyldibenzothiophene and 4,6-dimethyldibenzothiophene, Polyhedron, 1997, 16, 3213-3217.

2 X. Ma, K. Sakanishi and I. Mochida, Hydrodesulfurization reactivities of various sulfur compounds in vacuum gas oil, Ind. Eng. Chem. Res., 1996, 35, 2487-2494.

3 R.W. Howarth and R. Santoro, A. Ingraffea, Methane and the greenhouse-gas footprint of natural gas from shale formations, Clim. Change, 2011, 106, 679-690.

4 P. Barbara, M.N. Rufino, J.M. Campos-Martin and J.L.G. Fierro, Towards near zero-sulfur liquid fuels: a perspective review, Catal. Sci. Technol., 2011, 1, 23-42.

5 D.J. Monticello, Biodesulfurization and the upgrading of petroleum distillates, Curr. Opin. Biotechnol., 2000, 11, 540-546.

6 J.H. Chang, Y.K. Chang, K.S. Cho and H.N. Chang, Desulfurization of model and diesel oils by resting cells of Gordona sp., Biotechnol. Lett., 2000, 22, 193-196.

7 M. Soleimani, A. Bassi and A. Margaritis, Biodesulfurization of refrac- 
tory organic sulfur compounds in fossil fuels, Biotechnol. Adv., 2007, 25, 570-596.

8 J.H. Chang, S.K. Rhee, Y.K. Chang and H.N. Chang, Desulfurization of diesel oils by a newly isolated dibenzothiophene-degrading Norcadia sp. strain CYKS2, Biotechnol. Prog., 1998, 14, 851-855.

9 J.M. Campos-Martin, M.C. Capel-Sanchez, P. Perez-Presas and J.L.G. Fierro, Oxidative processes of desulfurization of liquid fuels, J. Chem. Technol. Biotechnol., 2010, 85, 879-890.

10 K. Kodama, K. Umehara, K. Shimizu, S. Nakatani, Y. Minoda and K. Yamada, Identification of microbial products from dibenzothiophene and its proposed oxidation pathway, Agric. Biol. Chem., 1973, $37,45-50$.

11 P.S. Tam, J.R. Kittrell and J.W. Eldridge, Desulfurization of fuel oil by oxidation and extraction. 2. Kinetic modeling of oxidation reaction, Ind. Eng. Chem. Res., 1990, 29, 324-329.

12 A. Chica, A. Corma and M.E. Dómine, Catalytic oxidative desulfurization (ODS) of diesel fuel on a continuous fixed-bed reactor, J. Catal., 2006, 242, 299-308.

13 L.J. Karas, R.A. Grey and M.W. Lynch, US Patent 047875, 2008.

14 F. Zannikos, E. Lois and S. Stournas, Desulfurization of petroleum fractions by oxidation and solvent extraction, Fuel Process. Technol., 1995, 42, 35-45.

15 T. Aida and D. Yamamoto, Annual Book of ASTM Standards, 2005. Standard test method for determination of sulfur compounds in natural gas and gaseous fuels by gas chromatography and chemiluminescence, Prepr. Pap. Am. Chem. Soc., Div. Fuel Chem., 1994, 39, 623.

16 S. Otsuki, T. Nonaka, N. Takashima, W. Qian, A. Ishihara, T. Imai and T. Kabe, Oxidative desulfurization of light gas oil and vacuum gas oil by oxidation and solvent extraction, Energy Fuels, 2000, 14, 1232-1239.

17 F.M. Collins, A.R. Lucy and C. Sharp, Oxidative desulfurization of oils via hydrogen peroxide and heteropolyanion catalysis, J. Mol. Catal. A: Chem., 1997, 117, 397-403.

$18 \mathrm{M}$. Te, C. Fairbridge and Z. Ring, Oxidation reactivities of dibenzodibenzothiophenes in polyoxometalate $/ \mathrm{H}_{2} \mathrm{O}_{2}$ and formic acid/ $/ \mathrm{H}_{2} \mathrm{O}_{2}$ systems, Appl. Catal. A, 2001, 219, 267-280.

19. Y. Shiraishi, K. Tachibana, T. Hirai and I. Komasawa, Desulfurization and denitrogenation process for light oils based on chemical oxidation followed by liquid-liquid extraction, Ind. Eng. Chem. Res., 2002, 41, 4362-4375.

20 F.M. Collins, A.R. Lucy and C.J. Sharp, Oxidation desulphurization of oils via hydrogen peroxide and heteropolyanion catalysis, J. Mol. Catal. A, 1997, 117, 397-403.

21 H. Mei, B.W. Mei and T.F. Yen, A new method for obtaining ultra-low sulfur diesel fuel via ultrasound assisted oxidative desulfurization, Fuel, 2003, 82, 405-414.

22 S. Otsuki, T. Nonaka, N. Takashima, W. Qian, A. Ishihara, T. Imai and T. Kabe, Oxidative desulfurization of light gas oil and vacuum gas oil by oxidation and solvent extraction, Energ. Fuel., 2000, 14, 1232-1239.

23 Y. Shiraishi and T. Hirai, Desulfurization of vacuum gas oil based on chemical oxidation followed by liquid-liquid extraction, Energ. Fuel., 2004, 18(1), 37-40.

24 T. Hirai, Y. Shiraishi and I. Komasawa, Desulfurization process for benzodibenzothiophenes from light oil by photochemical reaction and liquid-liquid extraction, Ind. Eng. Chem. Res., 1996, 35, 586-89.

25 W. Adam, W.A. Herrmann, J. Lin and C.R. Saha-Moller, Catalytic oxidation of phenols to p-quinones with the hydrogen peroxide and methyltrioxorhenium(VII) system, J. Org. Chem., 1994, 59, 8281-8283.

26 A.S. Ogunlaja, W. Chidawanyika, E. Antunes, M.A. Fernandes, T Nyokong, N. Torto and Z.R. Tshentu, Oxovanadium(IV) catalysed oxidation of dibenzothiophene and 4,6-dimethyldibenzothiophene, Dalton Trans., 2012, 41-45, 13908-13918.

27 A.S. Ogunlaja, S. Khene, E. Antunes, T. Nyokong, N. Torto and Z.R. Tshentu, The development of catalytic oxovanadium(IV)-containing microspheres for the oxidation of various organosulfur compounds, Appl. Catal., A, 2013, 462-463, 157-167.

28 Z.R. Tshentu C. Togo and R.S. Walmsley, Polymer-anchored oxovanadium(IV) complex for the oxidation of thioanisole, styrene and ethylbenzene, J. Mol. Cat. A: Chem., 2010, 318, 30-35.

29 R.S. Walmsley and Z.R. Tshentu, Imidazole-based vanadium complexes as haloperoxidase models for oxidation reactions, S. Afr. J. Chem., 2010, 63, 95-104.

30 R.S. Walmsley, A.S. Ogunlaja, M.J. Coombes, W. Chidawanyika, C. Litwinski, N. Torto, T. Nyokong and Z.R. Tshentu, Imidazolefunctionalized polymer microspheres and fibers - Useful materials for immobilization of oxovanadium(IV) catalysts, J. Mater. Chem., 2012, 22, 5792-5800.

31 R.S. Walmsley, P. Hlangothi, C. Litwinski, N. Torto, T. Nyokong and Z.R. Tshentu, Catalytic oxidation of thioanisole using oxovanadium(IV)-functionalized electrospun polybenzimidazole nanofibers. J. Appl. Polym. Sci., 2012, 127, 4719-4725.

32 R.S. Walmsley, S. Chigome, N. Torto and Z.R. Tshentu, Towards the development of fiber-based oxidovanadium(IV) catalysts for the oxidation of thioanisole, Catal. Lett., 2012, 142, 243-250.

33 R.S. Walmsley, C. Litwinski, E. Antunes, P. Hlangothi, E. Hosten, C. McCleland, T. Nyokong, N. Torto and Z.R. Tshentu, Oxovanadium(IV)-containing poly(styrene-co-4'-ethenyl-2-hydroxyphenylimidazole) electrospun nanofibers for the catalytic oxidation of thioanisole, J. Mol. Cat. A: Chem., 2013, 379, 94-102.

34 O.E. Fayemi, A.S. Ogunlaja, P.F.M. Kempgens, E. Antunes, N. Torto, T Nyokong and Z.R. Tshentu, Adsorption and separation of platinum and palladium by polyamine functionalized polystyrene-based beads and nanofibers, Miner. Eng., 2013, 53, 256-265.

35 K. Nakamoto, Coordination Compounds in Infrared and Raman Spectra of Inorganic and Coordination Compounds, 4th edn., John Wiley \& Sons, New York, USA, 1986.

36 L.K. White, N.D. Chasteen, A Q-band electron paramagnetic resonance study of Vanadyl(IV)-labeled human serotransferrin, J. Phys. Chem., 1979,83, 279-284.

37. Bruker, APEX2. Version 1-0. Bruker AXS Inc., Madison, Wisconsin USA, 2009.

38. G.M. Sheldrick, A Short History of SHELX, Acta Crystallogr., 2008, A64, 112-122.

39 L.J. Farrugia, WinGX and ORTEP for Windows: An Update, J. Appl. Cryst. 2012, 45, 849-854. 